Volume 8, Nomor 2, 2020

E-ISSN: 2621-5101 P-ISSN:2354-7294

\title{
KETIDAKSANTUNAN BERBAHASA PADA ISLAMOPHOBIA DI MEDIA SOSIAL
}

\author{
Mu'aliyah Hi Asnawi \\ mualiyah@unismuh.ac.id \\ Universitas Muhammadiyah Makassar
}

\begin{abstract}
The writer of this article intended to analyze the image of the disrespectful utterance of Islamophobia in social media. The method of qualitative research and an inductive approach was used for the whole research process. The textual data of term of Islamophobia by the social media users and the discourse analysis method were used in this article. The decision of this article was the phenomenon of the disrespectful utterance of Islamophobia in social media could be identified into two aspects according to its' source. The first aspect was the term of Islamophobia were constructed by the external side, by the non-muslims, by the Westerns, which Islam pictured stereotypically by this group. The second aspect was the term of Islamophobia manifested from the internally Muslims, which various expressions from the radical Islam group in social media supported the beginning of Islamophobia perception.
\end{abstract}

Keywords: Politeness, language, pragmatic, social media, islamophobia.

\section{PENDAHULUAN}

Islam sesungguhnya adalah agama rahmatan lil alamin, yang memberikan kasih sayang terhadap seluruh umat manusia di dunia ini (QS. al-Fath: 4). Namun citra dan penggambaran Islam baik dalam realitas nyata maupun di dunia maya terkadang menyimpang dari esensinya sebagai agama kedamaian. Muncul berbagai konstruksi sosial tentang Islam sebagai agama terorisme, radikalisme, ekstremisme dan istilah lain yang memberi kesan bahwa Islam agama yang menakutkan.

Label tersebut secara tidak langsung menciptakan paham anti Islam atau menyulut kebencian umat lain terhadap umat muslim yang pada gilirannya terbentuk persepsi "Islamophobia" di tengah masyarakat. Islamphobia diartikan sebagai rasa takut yang tidak berdasar terhadap umat Muslim di tataran individual dan psikologis, namun juga dapat terlembagakan dalam kebijakan dan kebiasaan masyarakat (George, 2017).
Islamophobia

merupakan ketakutan, kebencian dan permusuhan terhadap Islam dan muslim yang diabadikan oleh stereotype negatif yang mengakibatkan bias, diskrimiasi, marginalisasi dan eksklusi muslim dari kehidupan sosial, politik dan sipil (Wajahat Ali, 2011).

Menurut Komaruddin Hidayat (2019), Islamophobia secara historis dapat dilacak awal pertumbuhannya sejak Perang Salib antara umat Islam dan Kristen, yang membuat kedua agama ini berkembang di wilayahnya masing-masing. Islam di negara Timur dan Kristen di bagian Barat. Jejak hostoris perang Salib tersebut hingga dewasa ini masih tertanam dibenak masyarakat. Akar dari Islamofobia adalah perbedaan teologi atau keyakinan beragama dan perbedaan kemajuan dari segi teknologi (https://republika.co.id).

Islam disebut sebagai pengganti kekuatan Nazi maupun komunis yang mengandung gambaran tentang invasi dan infiltrasi. Hal ini mengacu pada ketakutan dan kebencian terhadap Islam dan 


\section{0 | JURNAL ILMU BUDAY}

Volume 8, Nomor 2, 2020

berlanjut pada ketakutan serta rasa tidak suka kepada sebagian besar orang-orang Islam. Kebencian dan rasa tidak suka ini berlangsung di beberapa negara barat dan sebagian budaya di beberapa negara (Trust, 1997).

Pada realitasnya, Islamophobia masih sering terjadi di berbagai negara, termasuk sebaran wacana Islamophobia di media massa konvensional dan jejaring media sosial (Saputra, et al., 2020). Sebagai contoh kasus dalam laporan riset oleh tim Centre for Islamic Studies and Civilisation dari Charles Sturt University (CSU) Australia (18/11/2019) yang menganalisis 349 insiden yang dilaporkan antara tahun 2016 dan 2017, menyimpulkan bahwa; wanita berjilbab di tempat keramaian paling sering alami pelecehan berbau Islamophobia; serangan Islamophobia yang berakibat korban harus masuk RS di Australia meningkat 3 persen; kehadiran anak kecil sama sekali tak menghentikan tindakan Islamophobia, dan beberapa kasus pelecehan kian meningkat (https://www.tempo.co).

Kasus serupa juga terjadi di Amerika Serikat, di mana penyebar Islamofobia menjadi kelompok terdepan dalam melakukan pelintiran kebencian. Mereka mengobarkan kemarahan terhadap pembangunan tempat ibadah Muslim, buku pelajaran yang memuat penjelasan yang baik mengenai agama Islam, serta tudingan pengaruh hukum Islam terhadap hukum AS (George, 2017).

Berbagai penelitian pun telah dilakukan oleh para akademisi untuk melacak proses penyebaran propaganda Islamopohobia melalui media massa dan media online (Tania, 2018, Kaharuddin \& Hasyim, 2020). Hasil riset Wijaya misalnya memaparkan bahwa sepanjang tahun 2002 di Indonesia, media Barat terutama di AS cenderung tidak berimbang dalam memberitakan seputar isu terorisme global. Ada kecenderungan sebagian media di Barat mengidentikkan Islam melalui pemberitaannya sebagai ajaran
E-ISSN: 2621-5101 P-ISSN:2354-7294

kekerasan dan umat Islam sebagai dalang terorisme global. Hal ini dibuktikan dengan pemberitaan miring terkait terorisme di beberapa media Barat seperti USA Today, Time Magazine, The Washington Post, The New York Times, The Straight Times dan lainnya (Wijaya, 2010).

Hasil penelitian kolaboratif antara dosen Universitas Islam Negeri Sunan Ampel dengan dosen di program Magister di Institute of Linguistics di Adam Mickiewicz of University Ponzan Polandia, mengungkapkan bahwa propaganda anti Islam yang berkembang di media Polandia menjadi sumber yang memperkuat Islamophobia. Media telah mengidentikkan Islam dengan Osama bin Laden, pemboman World Trade Center (WTC), sumber terorisme, perang Timur Tengah, dan bentuk-bentuk kekerasan lain. Stigma ini diperkuat dengan gambaran media bahwa Muslim direpsentasikan sebagai orang-orang yang tidak dapat atau tidak bisa berintegrasi dengan masyarakat Eropa, dan agamanya tidak sesuai dengan nilainilai Barat tentang kebebasan dan persamaan (Jauharoti Alfin, 2018)

Hasil riset Yuliarti juga berkesimpulan bahwa CNN.com sebagai media barat merepresentasikan diri dalam pemberitaan sangat tidak pro terhadap Islam, dengan mengaitkan Islam dan ISIS dalam berbagai kesempatan (Yuliarti, 2017). Dari beberapa hasil penelitian tersebut menunjukkan bahwa tindakan Islamophobia selain marak terjadi di beberapa negara, sebaran wacana Islamophobia juga masih sering mewarnai sajian informasi media massa.

Keberadaan jejaring media sosial sebagai sarana komunikasi virtual yang tengah digandrungi oleh sebagian besar masyarakat Indonesia, juga tidak luput dari proses penyebaran pesan atau propaganda kebencian terhadap Islam (Hasyim et al., 2020, Prasuri et al, 2020). Media sosial kadang membiarkan para penggunanya mengunggah status dan foto-foto yang 


\section{1 | JURNAL ILMU BUDAY}

Volume 8, Nomor 2, 2020

menggambarkan

Islamophobia

(Burhanuddin \& Hasyim, 2019). Ironinya pemilik akun yang melecehkan Islam pun tidak ditutup meski ada pengaduan kepada akun media sosial tersebut (Maknun, 2t al., 2019).

Jangkauan media sosial yang luas dan cepat meniscayakan penyebaran pesan atau pandangan-pandangan bernada Islamofobia secara intens (Arafah \& Hasyim, 2019. Para penghasut sengaja memanfaatkan media sosial untuk melancarkan propaganda Islamofobia melalui bahasa dan ujaran-ujaran tertentu sehingga membangkitkan kemarahan dan keterhasutan pengguna media sosial. Beranjak dari latar permasalahan dan komparasi penelitian terdahulu serta landasan teoretis, maka menarik dan penting untuk menganalisis bagaimana gambaran ketidaksantunan berbahasa pada Islamophobia di media sosial.

\section{METODE}

Artikel ini menggunakan metode kualitatif yakni pendekatan induktif terhadap seluruh proses penelitian. Artikel ini menggunakan data-data yang bersumber dari teks media sosial berupa penggunaan bahasa propaganda Islamophobia oleh pengguna media sosial. Metode analisis data yang digunakan adalah analisis wacana yang digunakan untuk menganalisis bahasa baik dalam bentuk tulisan ataupun lisan dengan menghubungkan antara teks dan konteks (Eriyanto, 2008).

\section{HASIL DAN PEMBAHASAN Ketidaksantunan Berbahasa Pada Islamophobia di Media Sosial}

Berdasarkan hasil analisis tentang ketidaksantunan bahasa pada Islamophonia di media sosial, setidaknya dapat dididentifikasi dua sumber utama munculnya narasi Islamophobia di media sosial tersebut. Pertama, bahasa Islamophobia yang dikonstruksi oleh pihak

\section{E-ISSN: 2621-5101 P-ISSN:2354-7294}

eksternal, yaitu non muslim, pihak Barat atau Amerika Serikat dan sekutunya, dan berbagai sebutan lain sejenisnya, di mana Islam digambarkan secara stereotipe oleh kelompok ini. Kedua, bahasa Islamophobia yang bersumebr dari internal umat muslim, di mana ekspresi kelompok Islam radikal di media sosial turut menopang persepsi Islamophobia.

Kedua dimensi Islamophobia tersebut selanjutnya dikaitkan dengan sampel kasus yang aktual terjadi di media sosial. Pada poin pertama, sebagaimana uraian beberapa studi terdahulu, menunujukkan bahwa Islamophobia merupakan hasil rekayasa sosial oleh pihak Barat untuk menyudutkan Islam dan umatnya. Salah satu strateginya adalah memunculkan isu anti terorisme global demi menghimpun kekuatan melawan negara Timur atau Islam. Di balik isu anti terorisme inilah pihak Barat menyebar propaganda Islamophobia sehingga umat lainnya membenci Islam.

Label terorisme pun disematkan bagi umat Islam yang dianggap membahayakan kehidupan umat lain karena gencar mewacanakan isu-isu terorisme berbalut gerakan jihad yang identik dengan ajaran Islam. Komaruddin Hidayat (2019) bahkan menyatakan bahwa kekuatan ekspansi kapitalisme dan media sosial yang dikuasai oleh Barat menjadi salah satu instrumen penyebar wacana Islamophobia.

Berdasarkan hasil penelusuran data ditemukan beragam teks media sosial yang bernada Islamophobia. Dalam situs arrahmah.com misalnya menyatakan bahwa Twitter dan Facebook adalah dua di antara sekian banyak platform media sosial yang cenderung memfasilitasi penyebaran konten Islamophobia. Terdapat ribuan postingan Islamofobia yang marak beredar di kedua situs media sosial tersebut tanpa sensor.

Dalam praktiknya, penyebaran konten Islamophobia di media sosial tersebut mengekspresikan bahasa yang 


\section{2 | JURNAL ILMU BUDAYA}

Volume 8, Nomor 2, 2020

tidak santun atau lebih cenderung merendahkan ajaran agama Islam. Bentuk ketidaksantunan bahasa pada pelaku Islamophobia ini dapat dilihat misalnya dalam laporan yang dirilis oleh Council on American Islamic Relations (CAIR) tentang Islamophobia di Amerika Serikat (https://republika.co.id).

Dalam laporan CAIR yang bekerja sama dengan University of California, Los Angeles (UCLA) menguraikan beberapa bentuk ketidaksantunan bahasa Islamophobia yang menjadi perbuncangan di media sosial, di antaranya:

Mantan senator AS Rick Santorum mengatakan:

"Demokrasi tak bisa diterapkan (di Islam) karena Muhammad (Nabi Muhammad SAW) sudah membuat hukum yang baku. Alquran ya sudah begitu saja, tak bisa diubah atau ditafsirkan lain, karena itu dia hanya ditulis untuk orang Islam". (17 Februari 2009).

Calon anggota kongres di AS, Lynne Togerson mengatakan:

"Islam menyetujui kekerasan dan kriminalitas. Oleh sebab itu, orang Islam seharusnya tak dilindungi hukum AS" (10 Desember 2009)

Anggota Dewan Kota Lancaster California, Sherry Marquez yang memposting tulisan di wall Facebook-nya:

"Inilah agama Islam sesungguhnya. Hukum pancung, membunuh yang didukung negara, ini yang akan datang ke rakyat AS" (28 Jannuari 2010).

Pendeta Terry Jones mengancam akan membakar 200 Alquran 11 September 2010). Selian itu, Pendeta lokal yang menentang pembangunan masjid di Temecula California mengatakan:

\section{E-ISSN: 2621-5101 P-ISSN:2354-7294}

"Pengaruh Islam tidak dominan di sini dan kami tidak ingin melihat Islam menyebar" (18 Juli 2010).

Bakal calon gubernur Tennessee AS, Ron Ramsey mengatakan:

"Islam bukanlah agama melainkan sebuah sekte" (27 Juli 2010)

Anggota Kongres asal Florida AS, Allan West mengatakan:

"Islam adalah ideologi politik yang totaliter. Islam bukanlah agama. Islam bukanlah agama bahkan sejak 622 Masehi" (9 November 2010).

Dari beberapa sampel teks Islamophobia tersebut di atas, menunjukkan kecenderungan bahwa para pemuka pendapat (opinion leader) di AS utamanya para politisi, pejabat publik dan tokoh agama lebih dominan menyuarakan Islamophobia, sehingga sudut pandang masyarakat awam ikut terpengaruh dengan propaganda tersebut. Faktanya pada 7 Agustus 2010, sejumlah warga yang terhasut propaganda Islamophobia melakukan demosntrasi di depan masjid Connecticut, membawa spanduk dan mengatakan "Islam adalah kebohongan, Yesus membenci Islam". Beberapa demonstran juga meneriakkan kata-kata "kamu pembunuh" kepada seorang anak yang keluar dari masjid tersebut.

Berbagai tutur bahasa yang tidak santun tidak hanya diaktualkan oleh pelaku Islamophobia melalui media sosial, namun juga dalam bentuk aksi nyata intimidasi terhadap umat muslim di beberapa wilayah di AS. Bahkan juga dalam bentuk tagline iklan "Stop Islamisasi di AS" yang bertujuan menentang pendirian Pusat Kegiatan Islam di WTC dan selebaran yang berbunyi "kami adalah Amerika Serikat, bukan negara Islam" yang tujuannya menentang pembangunan masjid di kota Florence, Kentucky.

Pesan bernada Islamophobia atau anti Islam melalui media sosial tentu akan 


\section{3 | JURNAL ILMU BUDAYA}

Volume 8, Nomor 2, 2020

sangat efektif jika yang menuturkan pesan itu adalah para pemuka pendapat (pejabat publik, politisi, dan tokoh agama). Hal ini sejalan dengan teori pengaruh komunikasi massa (pesan media) terhadap audiens. Lazarsfeld (1940) dalam penelitian tentang pengaruh media massa terhadap perilaku pemilih dalam kampanye pemilu di New York, menyimpulkan bahwa pengaruh media massa disaring oleh pemuka pendapat dan pengaruh interpersonal lebih dominan daripada media massa (Rakhmat, 2009).

Jika bersandar pada pendapat Lazarsfeld maka ini berarti pesan yang bernada Islamophobia di media sosial relatif lebih besar pengaruhnya apabila diartikulasikan oleh pemuka pendapat. Kecenderungan inilah yang terjadi di Amerika Serikat, para pemuka pendapat sangat gencar dalam menyuarakan propaganda Islamophobia sehingga berhasil menyulut amarah dan kebencian sejumlah warga terhadap umat muslim.

Kemudian terkait poin kedua yang telah disinggung di muka, realitas bahasa Islamophobia di media sosial juga sedikit banyak bersumber dari internal umat Islam sendiri. Dalam analisis Sarhindi (2017) misalnya mengurai fenomena ekspresi religiusitas di media sosial dengan mengatakan bahwa Gusdur sebetulnya telah memprediksi tentang ekspresi keberislaman yang cenderung formalistik dan simbolik, dan kecenderungan itu semakin tampak dalam perilaku bermedia sosial masyarakat (https://news.detik.com).

Dalam riset Nasrullah dan Rustandi (2016) menjelaskan bahwa bahasa agama yang berasal dari media sosial menunjukan gambaran tentang agama (Islam) yang berbeda, bahkan bertolak belakang secara makna. Hasil penelusuran di google.co.id dengan kata kunci "meme Islam" memunculkan hasil yang bertolak belakang dengan makna Islam itu sendiri. Banyak meme yang muncul yang justru memberikan citra buruk Islam seperti terorisme (Rustandi, 2016).

\section{E-ISSN: 2621-5101 P-ISSN:2354-7294}

\begin{tabular}{lll}
\multicolumn{3}{c}{ Bahasa agama dalam media sosial } \\
tentunya sangat & kompleks dan \\
menunjukkan realitas & sesungguhnya & dari
\end{tabular} Islam; Islam moderat, Islam nusantara, Islam liberal, Islam radikal dan berbagai penggambaran wajah Islam lainnya. Namun demikian, entitas media sosial yang membuka ruang kebebasan berekspresi bagi khalayak memunculkan problem yang serius, kini siapapun berpeluang menjadi narasumber keagamaan meski tidak berkompeten, Marc Sageman (2016) berpendapat bahwa muatan online, khususnya imam-imam yang populer di dunia maya, tidak memiliki "kekuatan intrinsik untuk memengaruhi orang menjadi tentara guna melawan Barat, tetapi hanya memperkuat pembentukan pandangan" (Amin Mudzakkir, 2018).

Argumen tersebut menunjukkan bahwa kelompokkelompok ekstremis memanfaatkan platform media sosial untuk menyebarkan propaganda, dengan menarik perhatian orang melalui daya tarik psikologi, intelektual, dan emosional. Dalam konteks ini, seseorang terpapar radikalisasi melalui pendekatan lunak.

Berbanding lurus dengan kenyataan semakin intensnya khalayak mengakses informasi keagamaan tanpa didasari sikap tabayyun, mengecek kebenaran informasi lebih dalam. Akibatnya khalayak media sosial yang awam sangat mudah terpengaruh virus radikalisme atau pemahaman eksklusif dalam beragama yang dibahasakan melalui media sosial. Temuan Adlina (2018) terkait penggunaan bahasa radikal pada sebuah akun instagram misalnya menyatakan:

"jika anda dihina seseorang silahkan
anda maafkan dia, namun jika Allah
swt dan Rasulullah saw dihina orang,
anda tidak berhak memaafkannya!"
(Adlina, 2018)

Tutur bahasa seperti di atas tentu tidak mencerminkan esensi ajaran Islam, 


\section{4 | JURNAL ILMU BUDAY}

Volume 8, Nomor 2, 2020

sehingga dikuatirkan dapat menggiring seseorang untuk menghalalkan segala cara seperti melakukan tindakan kekerasan, anarkis dan radikal yang diklaim sebagai upaya membela keyakinannya. Pada kasus lain, tersangka teroris Dian Yulia Novi, yang membawa bom panic saat upacara pergantian Paspampres di Istana Presiden, 11 Desember 2016, mengaku mengenal ajaran radikal melalui media sosial Facebook dalam rentang waktu setahun (Ulya, 2018).

Ketidaksatunan bahasa pengguna media sosial yang bernuansa Islamophobia juga dapat diidentifikasi melalui pesanpesan radikalisme dan intoleran. Menarik untuk diuraikan hasil riset International NGO Forum on Indonesian Development (INFID) bekerjasama jaringan GUSDURian berjudul "Persepsi dan Sikap Generasi Muda terhadap Radikalisasi dan Ekstremisme Kekerasan Berbasis Agama", pada tahun 2016 dengan sampling 1.200 responden di enam kota besar: Bandung, Makassar, Pontianak, Surabaya, Surakarta, dan Yogyakarta, dan mengamati melalui media sosial yang populer di kalangan pemuda, antara lain Twitter, Facebook, Instagram, WhatsApp, Telegram dan YouTube.

Riset tersebut melakukan pemetaan melalui dua cara; Pertama, pengamatan terhadap situs-situs online yang dianggap radikal; dan Kedua, pengamatan terhadap percakapan di media sosial. Pencarian data berdasarkan kata kunci yang dirumuskan lewat indikator untuk mengawasi ekstremisme oleh The International Centre for Counter-Terrorism (ICCT), yang berbasis di Den Haag.

Dalam hasil penelitian tersebut diuraikan beberapa kata kunci pemetaan untuk survei seperti "kafir, sesat, syariat Islam, tolak demokrasi, jihad, antek asing, komunis, liberal, pengkhianat agama dan musuh Islam". Dengan bantuan mesin, ditemukan kurang lebih 90 ribu akun yang memuat pesan radikal dan ekstremisme

\section{E-ISSN: 2621-5101 P-ISSN:2354-7294}

dalam waktu sebulan, kemudian dipilah akun berdasarkan jenis media sosial.

Dalam Twitter terdapat 20 akun yang paling sering mencuit dan mengicaubalik (retweet) pesan-pesan radikal atau ekstremis. Ada dua kata yang sering jadi konten kicauan, kata kunci terbanyak pertama ialah "kafir" dengan 5.173 kicauan, dan terbanyak kedua "komunis" sebanyak 995 kicauan dalam sebulan.

Dalam Telegram, ditemukan channel yang kerap menyampaikan pesanpesan radikal atau ekstremis, antara lain @ hizbuttahiririd (jumlah anggota 4.300), @ salamdakwah (13.600), @ salafyways (4.200), @jalananlurus (586), dan @forumkajianislamcikampek (115).

Dalam Facebook, ditemukan 884 unggahan memuat kata kunci yang tergolong radikal dan ekstremis. Dari 884 itu, terdapat 171 unggahan yang memuat kata kunci ekstremis sesuai indikator The International Centre for CounterTerrorism (ICCT).

Selain itu hasil penelitian Harianto (2018) juga menunjukkan bahwa radikalisme dalam konteks media sosial (Youtube) dikategorikan menjadi tiga, yakni, pertama, ceramah yang mengarah pada penolakan sistem bernegara yang sah, kedua, konten yang berisikan ujaran kebencian suku, ras dan agama, serta, ketiga, khutbah-khutbah yang mengajarkan tentang puritanisme (Harianto, 2018).

Dari beberapa riset tersebut dapat diidentifikasi bahwa sebaran konten radikalaisme di media sosial lebih dominan dikonstruksi melalui penggunaan bahasa yang eksklusif atau sarat dengan muatan pesan yang meyimpang dari ajaran Islam. Dalam konteks inilah Islamophobia akan terwujud karena persepsi khalayak media sosial lebih cenderung menilai secara negatif ajaran Islam; identik dengan paham anti demokrasi, doktrin kekerasan, bunuh diri berbalut jihad, teror dan perang serta berbagai narasi yang menyulut kebencian dan permusuhan. 


\section{5 | JURNAL ILMU BUDAY}

Volume 8, Nomor 2, 2020

Terkait dengan ketidaksantunan berbahasa pada Islamophobia yang lebih cenderung dimanifestasikan dalam berbagai konten radikalisme di media sosial, sebenarnya telah banyak aturan hukum yang dapat menjerat pelakunya. Misalnya dalam Pasal 156 KUHP melarang pernyataan yang mengandung rasa permusuhan, kebencian atau penghinaan terhadap suatu atau beberapa golongan rakyat Indonesia di muka umum. Demikian juga Pasal 157 KUHP ayat (1) merupakan salah satu pasal yang melarang ujaran kebencian, dengan menegaskan larangan menyiarkan, mempertunjukkan atau menempelkan di muka umum tulisan atau lukisan, yang isinya mengandung pernyataan rasa permusuhan, kebencian atau merendahkan di antara atau terhadap golongan-golongan rakyat Indonesia, dengan maksud supaya isinya diketahui atau lebih diketahui oleh umum.

Larangan ujaran kebencian juga diatur Pasal 28 ayat (2) UU No. 11/2008 jo UU Nomor 16 Tahun 2016 Tentang Informasi dan Transaksi Elektronik (ITE) melarang menyebarkan informasi yang ditujukan untuk menimbulkan rasa kebencian atau permusuhan individu dan/atau kelompok masyarakat tertentu berdasarkan atas suku, agama, ras, dan antargolongan (SARA) (Amin Mudzakkir, 2018).

Namun demikian bukan perkara mudah untuk menjerat pelaku ujaran kebencian karena relatif sulit mendeteksi keberadaan pelaku yang memanfaatkan media sosial untuk menyebar paham eksklusif, radikalisme dan intoleran yang meruntuhkan citra Islam tersebut. Meski demikian, hasil analisis Sarhindi (2017), setidaknya dapat menjadi rujukan untuk melihat beberapa model penggunaan akun media sosial untuk menyebar narasi radikalisme.

Pertama, menunggangi nama tokoh agama yang popular untuk meligitimasi fatwa keagamaan yang dibahasakan melalui media sosial. Umat muslim yang

\section{E-ISSN: 2621-5101 P-ISSN:2354-7294}

awam tentu akan mudah terpengaruh atau taklid buta karena cenderung terpapar informasi dari media sosial tersebut. Kedua, memanfaatkan akun yang diafiliasikan dengan ormas Islam tertentu dengan tujuan untuk menggalang para pengguna media sosial secara massif dan untuk melakukan indoktrinasi.

Ketiga, memanfaatkan akun palsu atau tanpa nama (anonym) namun secara intens dan eksplisit mengunggah pesanpesan yang bernada hoax dan provokatif. Keempat, membuat akun media sosial dengan nama-nama Islami. Seperti yang dilansir dari@TurnBackHoax, sebagian akun penyebar hoax memiliki nama-nama Islami di antaranya; muslimcyberarmy, Indonesiabertauhid, dakwah_tauhid, beritaislam212, suaraummat dan sejenisnya (https://news.detik.com).

Sejumlah oknum yang bersembunyi di balik akun media sosial tersebut dengan mudahnya menyampaikan sesuatu yang diklaim sebagai kebenaran yang bersumber dari ajaran Islam, namun tidak diketahui pasti sejauhmana kecakapan atau kompetensinya dalam bidang keagamaan.

Fenomena ini tentu akan berimplikasi seiring dengan meningkatnya ketergantungan masyarakat muslim pada media sosial. Maraknya konten yang bermuatan paham eksklusif, radikal dan intoleran di media sosial pada gilirannya mereduksi citra Islam bahkan dapat mengerucut menjadi Islamophobia. Persepsi publik akan Islam sebagai agama rahmatan lil alamin akan tercemar akibat tindakan dan tutur bahasa kaum muslim radikal yang dominan teraktualisasi di jejaring media sosial.

\section{KESIMPULAN}

Artikel ini menyimpulkan bahwa fenomena ketidaksantunan bahasa pada Islamophonia di media sosial, dapat dididentifikasi sumbernya dari dua aspek. Pertama, bahasa Islamophobia yang 


\section{6 | JURNAL ILMU BUDAYA}

Volume 8, Nomor 2, 2020

dikonstruksi oleh pihak eksternal, yaitu non muslim, pihak Barat, di mana Islam digambarkan secara stereotipe oleh kelompok ini. Kedua, bahasa Islamophobia yang dimanifestasikan dari internal umat muslim, di mana ekspresi keberagamaan dari kelompok Islam radikal di media sosial turut menopang lahirnya persepsi Islamophobia.

\section{DAFTAR PUSTAKA}

Arafah, B., Hasyim, M. (2019). The Language of Emoji in Social Media. KnE Social Sciences, 494-504.

Arafah, B., Hasyim, M. 2019. Linguistic functions of emoji in social media communication. Opción, Vol. 35, No. 24, 558-574.

Adlina, A. U. (2018). Agama dala Dimensi Politim dan Spiritualitas; Analisis terhadap Akun @Persatuan_pribumi. Masyarakat, Religi dan Tradisi Volume 04 No. O1 Juni .

Amin Mudzakkir, I. I. (2018). Menghalau Ekstremisme; Konsep dan Strategi Mengatasi Ekstremisme Kekerasan di Indonesia. Jakarta: Wahid Foundation dan Australia Indonesia Partnership for Justice 2 (AIPJ2).

Eriyanto. (2008). Analisis Wacana; Pengantar Analisis Teks Media. Yogyakarta: LKiS.

George, C. (2017). Pelintiran Kebencian; Rekayasa Ketersinggungan Agama. Jakarta: Pusat Studi Agama dan Demokrasi (PUSAD) Yayasan Paramadina.

Harianto, P. (2018). Radikalisme Islam dalam Media Sosial (Konteks; Channel Youtube). Jurnal Sosiologi Agama, Vol. 12, No. 2, Juli-Desember .

Hasyim, Muhammad. 2017. The Metaphor of Consumerism. Journal of Language Teaching and Research, Vol. 8, No. 3, pp. 523-530
E-ISSN: 2621-5101 P-ISSN:2354-7294

Hasyim, M., Prasuri Kuswarini, P., Kaharuddin. 2020. Semiotic Model for Equivalence and NonEquivalence in Translation. Humanities \& Social Sciences Reviews. 8 (3), 381-391.

Saputra, W.I., Muhammad Hasyim, Muhammad., Junus, Fierenziana G. 2020. Perspektif Media Prancis dalam Pemberitaan Pencemaran Air di Indonesia. Al-Munzir, Vol. 13. No. 1, 19-34.

Kaharuddin., \& Hasyim, M. (2020). The Speech Act of Complaint: SocioCultural Competence Used by Native Speakers of English and Indonesian. International Journal of Psychosocial Rehabilitation, 24(6), 14016-14028.

Intan, Tania. 2018. Narator Sebagai Penyampai Kritik Sosial Dalam Novel Moha Le Fou Moha Le Sage Karya Tahar Ben Jelloun. Jurnal Ilmu Budaya. 6 (2), 207-220

Jauharoti Alfin, A. M. (2018). Wacana Islamophobia dan Persepsi terhadap Islam Indonesia melalui Studi Bahasa di Kalangan Mahasiswa Polandia. Miqot, Vol. XLII No. 1 Januari-Juni .

Kuswarini, Prasuri, Muhammad Hasyim, M., Chotimah, Irma N.H. 2020. Othering The Self as A Form of Mimicry in The English Translation of Hirata's Laskar Pelangi. Journa of Critical Reviews. Vol 7, Issue 19, 12861295

Maknun, T., Hasjim, M., Muslimat, M. and Hasyim, M. 2019. The form of the traditional bamboo house in the Makassar culture: A cultural semiotic study. Semiotica. In press. https://doi.org/10.1515/sem-20170162

Rakhmat, J. (2009). Psikologi Komunikasi. Bandung: Remaja Rosdakarya.

Rustandi, R. N. (2016). Meme dan Islam; Simulakra Bahasa Agama di Media 
Sosial. Academic Journal for Homiletic Studies, Volume 10 Nomor 1.

Trust, R. (1997). Islamophobia: A Challenge For Us All. London: Runnymede Trust, Commission on British Muslims and Islamopbobia.

Ulya. (2018). Post Truth, Hoax dan Religiusitas di Media Sosial. Fikrah; Jurnal Ilmu Aqidah dan Studi Keagamaan, Vol.6, No. 2 .

Wajahat Ali, E. C. (2011). The Roots of The Islamophobia Network in America. Washington DC: Center for American Progress.

Wijaya, S. H. (2010). Media dan Terorisme; Stereotype Pemberitaan Media Barat dalam Propaganda Anti-Terorisme oleh Pemerintah Amerika Serikat. The Messengger, Volume II, Nomor 1, Edisi Januari

Yuliarti, H. C. (2017). ISIS dan Stigma Islamophobia; Framing tentang Konstruksi Pemberitaan ISIS di Media Online . Komunikasi Kareba, Vol.6 No.2 Juli Desember .

https://republika.co.id/berita/duniaislam/islammancanegara/11/06/24//nacp8laporan-islamophobia-as-daripolitisi-pejabat-publik-hinggawarga-semua-takut-akan-islam

https://www.arrahmah.com/2015/01/04/isl amophobia-berkembang-di-mediasosial/

https://www.pikiranrakyat.com/nasional/pr01320443/media-sosial-mengubahwajah-islam-di-indonesia https://dunia.tempo.co/read/632683/facebo ok-dituding-sebarkan-islamophobia 